\title{
The Prevalence of Alimentary Tract Worms in Domestic Cats and Stray Cats at Campus Area of Semarang State University, Central Java
}

\author{
(PREVALENSI CACING SALURAN PENCERNAAN PADA \\ KUCING LIAR DAN KUCING PELIHARAAN DI AREA KAMPUS \\ UNIVERSITAS NEGERI SEMARANG, JAWA TENGAH)
}

\author{
Rafita Farantika*, R. Susanti \\ Department of Biology, \\ Faculty of Mathematics and Natural Sciences, \\ Semarang State University \\ Kampus Unnes Sekaran, Sekaran, Gunungpati, \\ Semarang, Central Java, Indonesia, 50229 \\ Telp./fax: (024) 8508112, \\ Email: rafitafarantika21@gmail.com
}

\begin{abstract}
The aims of this study were to identify and measure the prevalence of alimentary tract worm in stray and domestic cats in the campus area of Semarang State University (Universitas Negeri Semarang/Unnes). As many as 30 cat feces samples: 10 stray cats samples (SC), 10 limited range domestic pet cats (LDC), and 10 indoor domestic pet cats (IDC) were used in this study. Examination of the feces samples was done by using the flotation method to identify the eggs of worms. Based on feces examination, eggs of four worms species i.e. Ancylostoma caninum, Clonorchis sinensis, Dipylidium caninum and Toxocara cati were found. Based the prevalence of worm eggs: A. caninum was found infected 4 out of 30 samples (13.3\%), C. sinensis was found infected 2 out of 30 samples (6.6\%), D. caninum was found infected 2 out of 30 samples $(6.6 \%)$, and $T$. cati was found infected 10 out of 30 samples $(33.3 \%)$.
\end{abstract}

Keywords: prevalence; alimentary tract worm; cats; Semarang StateUniversity

\begin{abstract}
ABSTRAK
Penelitian ini bertujuan untuk mengidentifikasijenis cacing dan mengukur tingkat prevalensi infeksi cacing pada kucing liar dan kucing peliharaan di wilayah kampus Universitas Negeri Semarang. Sebanyak 30 sampel kucing yaitu 10 kucing liar (SC), 10 kucing peliharaan yang bebas berkeliaran (LDC), dan 10 kucing peliharaan dalam rumah (IDC) digunakan dalam penelitian ini. Pemeriksaan feses pada kucing menggunakan metode apung/flotasi untuk mengidentifikasi telur cacing yang terdapat pada feses kucing. Pada penelitian ini teridentifikasi empat jenis cacing yang menginfeksi kucing liar dan peliharaan di area kampus Unnes yaitu Ancylostoma caninum, Clonorchis sinensis, Dipylidium caninum dan Toxocara cati. Berdasarkan prevalensi telur cacing: Ancylostoma caninum ditemukan menginfeksi 4 dari 30 sampel (13,3\%), Clonorchis sinensis ditemukan 2 dari 30 sampel (6,6\%), Dipylidium caninum ditemukan 2 dari 30 sampel (6,6\%), dan Toxocara cati ditemukan 10 dari 30 sampel (33,3\%).
\end{abstract}

Kata-kata kunci: prevalensi; cacing saluran pencernaan; kucing; Universitas Negeri Semarang 


\section{INTRODUCTION}

Cats are carnivorous animals that can be found in almost all over the world because of their excellent adaptability. As time went on, cats that were once known as religious symbols, have now become rat population controll and also one of the favorite animals. The population of cats in Indonesia, according to the World Society for the Protection of Animals (WSPA, 2008) is $15,000,000$ and ranks as the third most cat after the United States and Russia. With the large number of cats in Indonesia that spread in various cities, making cats not only maintained and lived in the wild.

Based on where they live, cats can be categorized into three, among others: 1) Domestic pet cats, 2) Stray cats and 3) Feral cats. Domestic pet cats are cats that live one house with their owners, the food needs are fully giving by the owner. Domestic pet cats are divided into three based on their roam space, that is Indoor, Limited range, and Free range. Home cats with the Indoor category are not allowed to leave the house and are usually tame, the Limited range category is cats that are allowed to leave the house, but are only limited to neighbors and are still under the supervision of the owner. Freerange cats are cats that are allowed to go anywhere by their owners without supervision usually, cats in this category are not all tame. Stray cats are cats that live freely in urban areas without owners who rely on food from humans but by finding their own food. Feral cats are cats that live wild in places far from human life like in the forest. Food obtained is from the results of hunting and none of its needs are provided by humans (Hildreth et al., 2010).

Many diseases that infect cats such as viruses, bacteria, fungi, and parasites. Types of the parasites that are often found in the alimentary tract of cats were Ancylostoma spp., Toxocara spp., Strongyloides spp., Toxoplasma gondii, Cryptosporidium spp., Sarcocystis spp., Echinococcus multilocularis, Giardia duodenalis, and Toxoplasma gondii (Oktaviana et al., 2014; Elmore et al., 2010). Factors that influence the prevalence of parasitic infections include environmental and animal factors. Environmental conditions for the highly influential infection of cat parasites. A dirty environment allows contamination of higher than pet cats (Nealma et al., 2013)

The prevalence of worms as the alimentary tract can vary due to geographical region. Several factors could affect the frequency of a species of the parasite in a population. Presence of veterinary care, habits of the local animal populations, a season of the year and the cat population composition (Abu-Madi et al., 2008). Internal parasites can decrease endurance by absorbing essential nutrients and interfering with vital organs (Agustina, 2013), the worm infection can make cats more susceptible to various diseases (Ward, 2009). Alimentary tract worm constitutes a major source of diseases for cats in the tropics and has been recognized as important public health problems in several parts of the world (Raji et al., 2013).

Many surveys regarding cat worms have been conducted in the world since a long time ago. The data of worms prevalence in feces cats reported in the Republic of Korea was $82.2 \%$. More than 29 worms species including adults or eggs were detected in visceral and feces samples of the examined cats. A variety of Cestodes, including Spirometra erinacei, Taenia taeniaeformis and unidentified species of tapeworm were detected (Sohn and Chai, 2005). In Romania reported that the overall prevalence of endoparasites in household cats was $34.3 \%$ (Mircean et al., 2010), the data also reported in Lisbon that found intestinal parasites in 23/74 samples and identified as T. cati, Isospora felis, Ancylostoma tubaeforme, Dipylidium caninum, Uncinaria stenocephala and T. Ieonine (Duarte et al., 2010). In Japan was reported $43.1 \%$ of cats infected by internal parasites (Yamamoto et al., 2009). Studies of alimentary tract worms of cats in several parts of the countries have been limited to the cat population (Raji et al., 2013).

Research on the prevalence of worm egg species in cat feces in the campus area of Semarang State University has never been done before. In Semarang City, there is no available information about the prevalence and distribution of alimentary tract worms in cats. Reports on the prevalence and spread of alimentary tract parasites can be used as consideration in taking action to control parasitic diseases.

Data on parasites in cats at the Bogor Agriculture University is a similar study in the campus area of Semarang State University. The prevalence of gastrointestinal worms in cats at the Bogor Agriculture University was $83 \%$. The identified parasites were hookworms, Toxocara spp., T. Ieonina, and Isospora felis (My et al., 2013). Given the potential of the alimentary tract parasite as a zoonotic agent, this research needs 
to be done to determine its existence. The aims of this study were to identify and measure the prevalence of alimentary tract worm in stray cats and domestic cats in the campus area of Semarang State University. Information obtained about zoonotic parasites can later provide awareness to the community on the Semarang State University about the dangers of zoonotic parasites.

\section{RESEARCH METHODS}

This research is exploratory research with survey method. Field survey of stray cats and pet cats was done in the campus area of Semarang State University. The sampling location chosen was based on purposive sampling technique. The sampling location was based on the existence of a large number of stray and pet cats and the environmental conditions that had been in the previous field survey in the campus area of Semarang State University.

There were 11 sampling locations such as Rectorate, Central Library, FBS (Faculty of Arts and Language), FIS (Faculty of Social Science), Kalimasada Road, Setanjung Alleyway, Cempakasari Alleyway, Pete Alleyway, Pisang Alleyway, Waru Alleyway, and Rambutan Alleyway. The sample examination was carried out in the Biology Department Laboratory, Faculty of Mathematics and Natural Sciences, Semarang State University.

The method used to identify and calculate worm eggs was plain flotation method. Observed under a light microscope worm eggs were identified based on structural according to Purnomo et al. (2009) and Prianto et al. (2001). All of the data were analyzed descriptively. Prevalence is how often a disease or condition occurs in a group of species (Pujiastuti, 2015). The formula used to analyze the level of infection with worms in cats was carried out by using prevalence calculations according to Oktaviana et al. (2014), as follows: Prevalence $=[$ (the number of samples infected with worms) $\mathrm{x}$ (the number of samples checked) $\left.{ }^{-1}\right] \times 100 \%$.

\section{RESULTS AND DISCUSSION}

As many as 30 cat feces samples: 10 stray cats samples (SC), 10 limited range domestic pet cats (LDC), and 10 indoor domestic pet cats (IDC). Based maintenance system, which stray cat was found infected with six positive of 10 samples $(60 \%)$, while the limited range domestic cat was
Table 1. The prevalence is based on the type of cat around the campus area of Semarang State University

\begin{tabular}{cccc}
\hline $\begin{array}{c}\text { Types } \\
\text { Cats }\end{array}$ & $\begin{array}{c}\text { Number } \\
\text { of cats sample }\end{array}$ & $\begin{array}{c}\text { Positive } \\
\text { samples }\end{array}$ & $\begin{array}{c}\text { Prevelance } \\
(\%)\end{array}$ \\
\hline SC & 10 & 6 & $60 \%$ \\
LDC & 10 & 3 & $30 \%$ \\
IDC & 10 & 1 & $10 \%$ \\
Total & 30 & 10 & $33.3 \%$ \\
\hline
\end{tabular}

Note: (SC) stray cats; limited range domestic pet cats (LDC); indoor domestic pet cats (IDC)

found infected with three positive of 10 samples $(30 \%)$, and indoor domestic pet cat was found infected one positive of 10 samples (10\%) (Table $1)$.

The results showed that the highest prevalence of worm infections in stray cats (SC) was $60 \%$ because stray cats that have no owners and live by in any place. Stray cats have uncontrolled breeding because its population increased continuously (Sucitrayani et al., 2014; Hilderth et al., 2010). Another factor that made of the high prevalence of worm infections in stray cats is because most cats forage in trash cans. Stray cats live in moist and dirty areas where these envinronments are ideal conditions for the development of an infective form of worm larvae (Oktaviana et al., 2014). Abu-Madi et al. (2008) state that geographical factors of a region can affect prevalence rates, other factors include climate, cat population in an area and space to roam from the cat itself.

Regional conditions (climate, humidity, temperature and soil conditions) are important things that may affect prevalence rates (Sucitrayani et al., 2014). Environmental conditions in the area of the Semarang State University have a tropical climate with a temperature of $30-34^{\circ} \mathrm{C}$, light intensity ranges from $520-870$ Lux, and humidity is $43-62 \%$. The tropical climate has high humidity so that it is a fertile ground for the life of parasitic worms. High humidity is an optimum condition for the development and dissemination of various species of worm disease (Sucitrayani et al., 2014). In other conditions according to Sures et al. (2017), the lower temperatures making egg development takes longer or inhibits egg development.

Limited range domestic pet cats (LDC) showed that the worm was infected $30 \%$, not much different from stray cats (SC), because the 
system of caring for cats were released outside the house even though the owner provided food and water to drink. Cats are kept outside the house usually facing directly to the outside environment, so they can be infected with worms. The infection may occur if cats swallow infective worm eggs on the ground or eat intermediate hosts (insects, earthworms, and snails that contain eggs or infective worm larvae), accidentally eat food in the neighborhood contaminated with infective eggs or larvae, and contact between infected cats or pollutant when

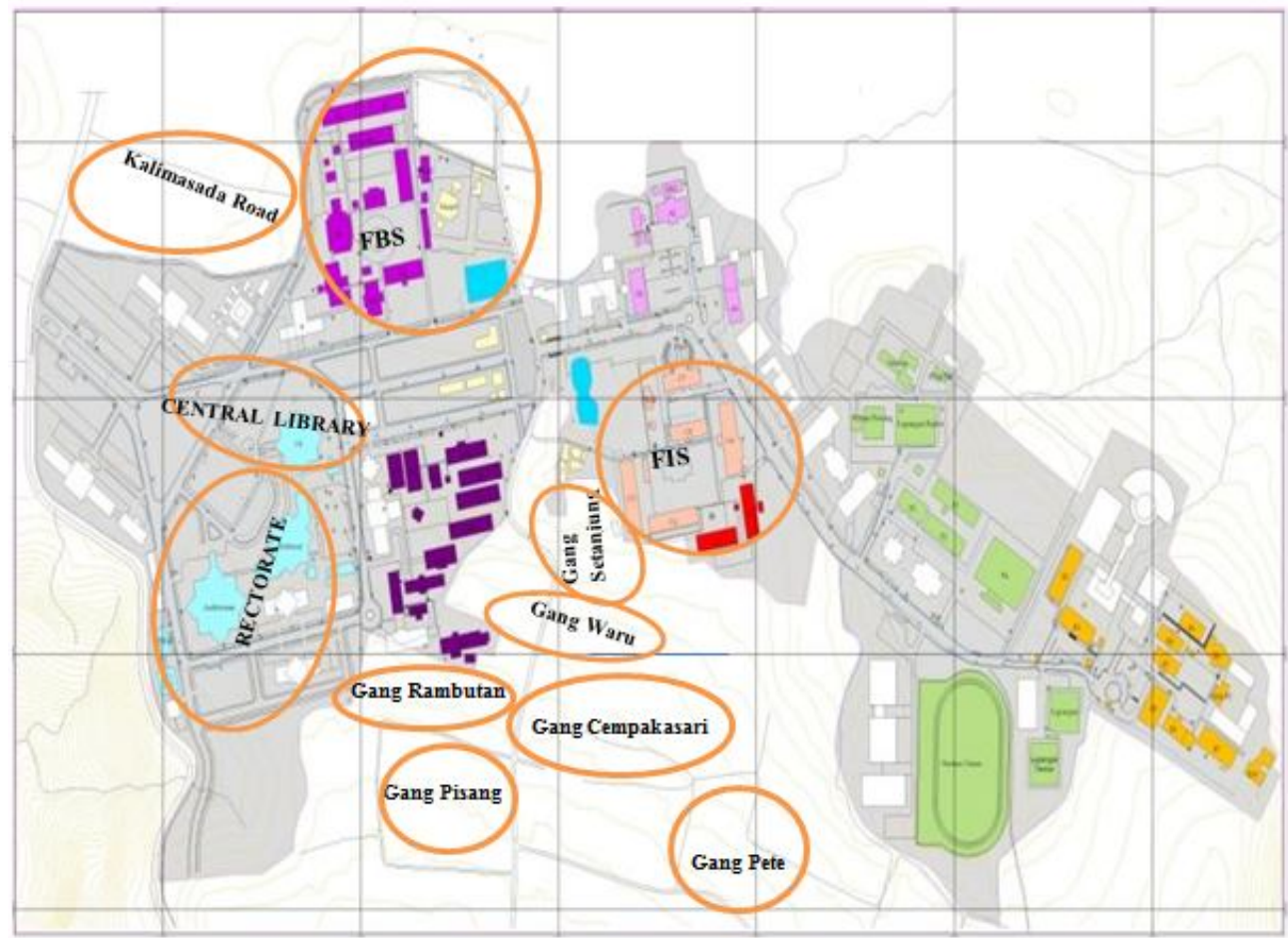

Figure 1. Map of sampling in the campus area of Semarang State University
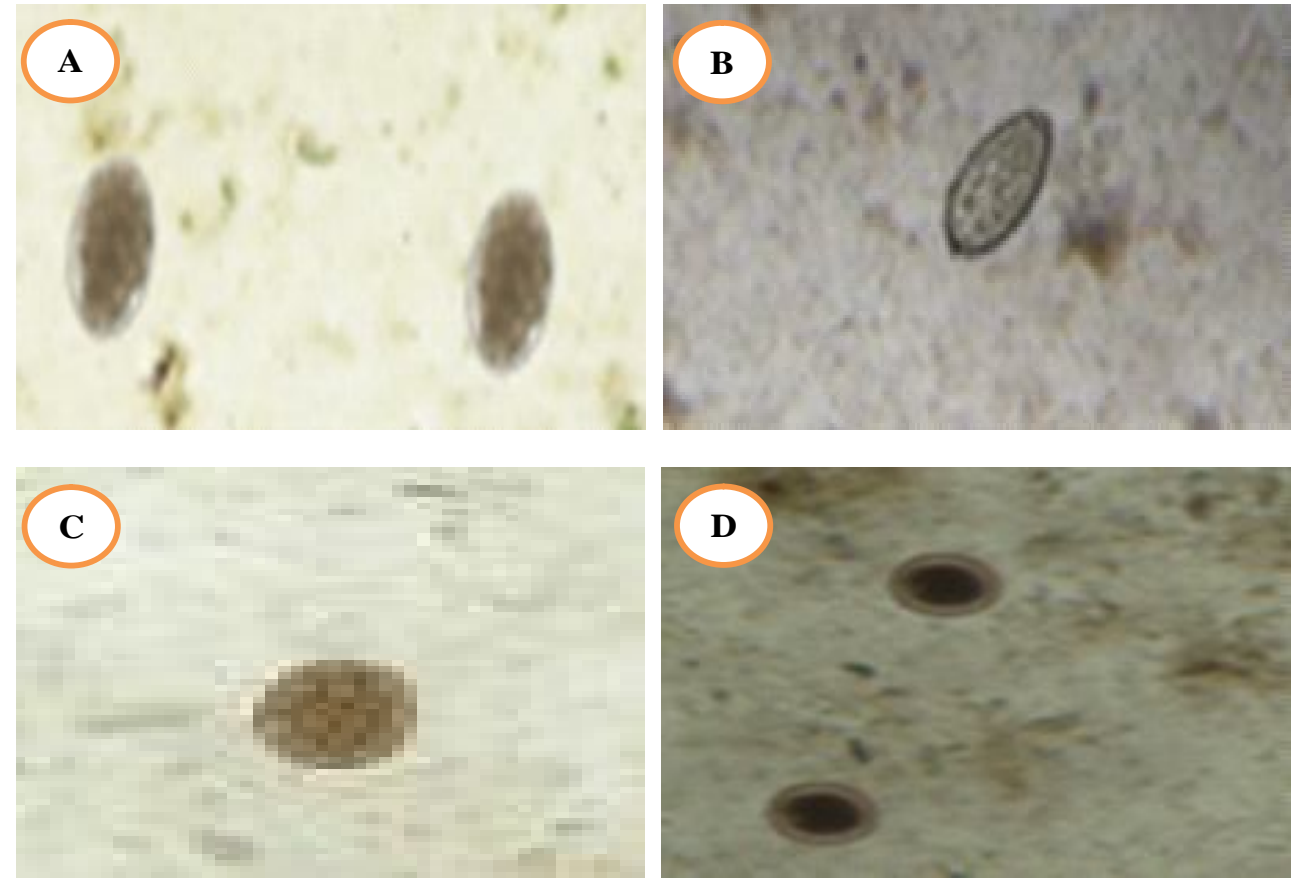

Figure 2. Result observation of worm eggs: (A) Ancylostoma caninum; (B) Clonorchis sinensis; (C) Dipylidium caninum; (D) Toxocara cati (40x10 objective magnification) 
cats are range outdoors (Loliwu and Thalib, 2012).

The lowest worm infection was found in indoor domestic pet cats (IDC), the prevalence was $10 \%$, because domestic pet cats (IDC) were maintained intensively by their owners. The cats have clean pens, their health is always considered and they were given routine vaccinations. Usually, this cat is tame and never leaves the house of its owner (Hilderth et al., 2010). Risk factors happen if the occurrence of infected pet cats were coincidence with the availability of sand as a place to defecate for cats. The availability of sand provided a risk to be infected with worm, compared to cats that are not given sand. It is suspected that infected cats remove worm eggs within the feces and enter into the sand, and then the eggs will multiply on the sand so that sand becomes a source of transmission of worm infections to the other cats. Transmission of worm infections can generally occur through direct contact with soil or sand containing infective larvae, i.e. third stage larvae, and then larvae directly penetrate the skin and migrate through blood vessels (Brentlinger et al., 2003).

The species of worm based on eggs found in this study were $A$. caninum, $C$. sinensis, $D$. caninum, and T. cati (Figure 2 ). The prevalence of $A$. caninum was found infected with four positive of 30 samples $(13.3 \%)$, C. sinensis was found infected with two positive of 30 samples $(6.6 \%), D$. caninum was found infected with two positive of 30 samples $(6.6 \%)$, and $T$. cati was found infected with 10 positive of 30 samples (33.3\%) (Table 2).

The prevalence of alimentary tract worm in stray cats (SC), limited range domestic (LDC) pet cats, indoor range domestic pet cats (IDC) in the area of Semarang State University was presented in Tabel 2. The result showed that the prevalence of T. cati in Semarang State University was highest (33.3\%) from all prevalence types of worms infection in cats, compared to other research in Iran, such as
Zibaei et al. (2007) reported 92,9\% of stray cats infected by Toxocara spp. The prevalence of Toxocara spp. in cats in Europe have been reported in Italy, Riggio et al. (2013) found $T$. cati in $22 \%$ of cat feces samples. In Spain, Gracenea et al. (2009) found T. cati eggs in $22 \%$ of cat feces samples with distinct higher incidence in kittens. In Romania, $T$. cati were infected $20.3 \%$ of household cats (Mircean et al., 2010), Epe et al. (2004) detected T. cati eggs in $3,9 \%$ of feline fecal samples in Germany, while Barutzki and Schaper (2003) found Ascarids eggs in $6.4 \%$ of fecal samples. In Denpasar, (Nealma et al., 2013) reported $60 \%$ stray cats infected by T. cati.

This could play a significant role in contributing to the incidence of cutaneous larva migrans in the human population. Toxocara cati is an ascarid nematode which was the next most common intestinal parasite observed in this study with a relatively high prevalence of $33.3 \%$. The high prevalence of $T$. cati infection recorded poses a high risk to humans in view of the large number of eggs about 200,000 eggs produced per day by a female of this parasite that are deposited in the soil along with cat's feces (Glickman and Schantz, 1981). These eggs can survive for a long time in the environment and could be accidentally ingested by humans in which they can cause visceral larva migrans or human Toxocariasis due to larva migration, a commonly reported zoonotic helminthiasis (Holland and Smith, 2006).

The prevalence of $A$. caninum in stray cats and domestic pet cats in the area of Semarang State University was $13.3 \%$. It was lower than occurence in Brazil that was A. caninum (67.3\%) (Coelho et al., 2011). The prevalence in Korea was $33 \%$ in stray cats (Sohn and Chai, 2005), in Colombia which was $7.4 \%$ in house cats (Echeverry et al., 2012). The high or low prevalence of Anyclostoma spp. can be caused by ideal environmental conditions for its development. According to Bowman et al. (2002), the optimal temperature for the development of

Table 2. The worms prevalence in the cats of Semarang State University campus area

\begin{tabular}{lccc}
\hline Species of worm eggs identified & Positive samples & Prevelance (\%) & $\begin{array}{c}\text { Average Number } \\
\text { of worm egg }\end{array}$ \\
\hline Ancylostoma caninum & $4 / 30$ & $13.3 \%$ & 10 \\
Clonorchis sinensis & $2 / 30$ & $6.6 \%$ & 6 \\
Dipylidium caninum & $2 / 30$ & $6.6 \%$ & 3 \\
Toxocara cati & $10 / 30$ & $33.3 \%$ & 54 \\
\hline
\end{tabular}


Anyclostoma spp. larva were $20^{\circ} \mathrm{C}$. In addition, Anyclostoma spp. has the stability to actively infect stray and pet cats in various ages. The main transmission route of Anyclostoma spp. is through penetration into the skin directly by the third larvae (Bowman et al., 2002). Anyclostoma spp. larvae that normally mature in the alimentary tract worms of animals can cause cutaneous larva migrans in people. Zoonotic Anyclostoma spp. known to cause this condition include $A$. braziliense, $A$. caninum, $A$. ceylanicum, and A. tubaeforme. Other species of Anyclostoma spp. found in animals, including wildlife and captive exotics, might also be able to cause cutaneous larva migrants (Acha and Szyfres, 2003).

Cats are the definitive host of some Cestodes. Cestodes that have been reporting infected cats were Diphyllobothrium sp, Joyeuxiella sp, Spirometra $s p, D$. caninum, T. taeniaeformis and Echinococcus sp. The prevalence of D.caninum found in this research was $6.6 \%$. Other research reported that in Iranian stray cats detected Cestodes were Joyeuxiella pasqualei (34.3\%), D. caninum (49.5\%), T. Taeniaeformis (12.3\%) and Spirometra sp. (3.8\%) (Zibaei et al., 2007). The prevalence of cat Cestodes in Japan reported Spirometra erinaceieuropaei (8.3\%), $D$. caninum (1.4\%), Taeniidae $(0.2 \%)$ and $D$. nihonkaiense (0.1\%) (Yamamoto et al., 2009). Dipillydium latum is a tapeworm that has a serious attention of public health because it is a zoonotic agent. Some previous studies reported that thus tapeworms were infecting humans (Revenga,1993; Nicoulaud et al., 2005).

The prevalence of Clonorchis sinensis in this study was $6.6 \%$, Other research reported that result in Shantou (the eastern city of Guangdong province) was $2,1 \%$ in cats (Fang et al., 2007). Prevalence of $C$. sinensis infection in dogs and cats in subtropical southern China were 20,5\% and $41.8 \%$, respectively (Lin et al., 2011). C. sinensis has the potential to cause zoonotic disease in humans which called Clonorchiasis (Tang et al., 2016). Cats are infected with $C$. sinensis are likely because they eat fresh raw fish or undercooked fish that may contain metacercaria. Fish is one of the intermediate hosts of C. sinensis. Clonorchis sinensis can be transmitted to humans and animals by eating raw or undercooked fish containing metacercariae (Petney et al., 2013).

\section{CONCLUSION}

Types of worm eggs found in feces of cats in the study area were $A$. caninum, $C$. sinensis, $D$. caninum and T. cati. Based the prevalence of worm eggs, $A$. caninum was found infected with four positive of 30 samples $(13,3 \%)$, C. sinensis was found infected with two positive of 30 samples (6.6\%), D. caninum was found infected with two positive of 30 samples $(6.6 \%)$, and T. cati was found infected with 10 positive of 30 samples $(33.3 \%)$.

\section{SUGGESTION}

It is necessary to control diseases caused by infection of the alimentary tract worms in cats that are beneficial for the health of the cat. Cats lover need to pay attention to their health. In addition, further research is needed on alimentary tract worm epidemiology in cats.

\section{ACKNOWLEDGEMENT}

Many thanks to cat owners for permission and assistance in giving feces samples to be examined in this study and fellow students who helped in capturing cats used as samples of this study.

\section{REFERENCES}

Abu-Madi MA, Al-Ahbabi DA, Al-Mashadani MM, Al-Ibrahim R, Pal P, Lewis JW. 2008. Patterns of parasitic infections in faecal samples from stray cat populations in Qatar. J Helminth 81: 281-286.

Acha PN, Szyfres B. 2003. Zoonoses and Communicable Diseases Common to Man and Animals: Cutaneous Larva Migrans; Parasitoses. Sci Tech Pub 580: 249-52.

Agustina KK. 2013. Identification and Prevalence of Strongyle Type Worm in Pigs in Bali Indonesia. Bul Vet Udayana 5(2): 131-138.

Bashofi A, Soviana S, Ridwan, Y. 2015. Flea infestation and Dipylidium caninum (Linnaeus) infection on stray cat in campus area of Bogor Agricultural University, Dramaga Bogor. Jurnal Entomologgi Indonesia 12(2): 108-114.

Barutzki D, Schaper R. 2003. Endoparasites in Dogs and Cats in Germany 1999-2002. Parasitol Res 90(3): 148-150. 
Bowman DD, Hendrix CM, Lindsay DS, Barr SC. 2002. Feline Clinical Parasitology. Iowa (US). Iowa State University Pr.

Brentlinger PE, Capps L, Denson M. 2003. Hookworm infection and anemia in adult women in rural Chiapas Mexico City. Vet Parasitol 115: 176-180.

Coelho WMD, Amarante AFT, Apolinario JC, Coelho NMD, Bresciani KDS. 2011. Occurrence of Ancylostoma in Dogs, Cats and Public Places From Andradina city, Sao Paulo State, Brazil. Rev Inst Med Trop Sao Paulo 53(4): 181-184.

Duarte A, Castro I, Pereira da Fonseca IM, Almeida V, Adeira de Carvalho LM, Meireles J, Fazendeiro MI, Tavares L, Vaz Y. 2010. Survey of Infectious and Parasitic Diseases in Stray Cats at The Lisbon Metropolitan Area, Portugal. J Feline Med Surg 12(6): 441-446.

Echeverry DM, Giraldo MI, Castano JC. 2012. Prevalence of Intestinal Helminths in Cats in Quindío, Colombia. J Biomedica 32(3): 430-436.

Elmore, SA, Jones JL, Conrad PA, Patton S, Lindsay DS, Dubey JP. 2010. Toxoplasma gondii: Epidemiology, Feline Clinical Aspects, and Prevention. Trends in Parasitology 26(4): 190-196.

Epe C, Coati N, Schnieder T. 2004. Results of Parasitological Examinations of Faecal Samples from Horses, Ruminants, Pigs, Dogs, Cats, Hedgehogs and Rabbits Between 1998 and 2002. Dutsch Tierärztl Wochenschr 111: 243-247.

Fang YY, Wu J, Liu Q, Huang SY, Lin RX, Zhang QM, Ruan CW.2007 : Investigation and Analysis on Epidemic Status of Clonorchiasis in Guangdong Province. Chin J Pathog Biol 2: 54-56.

Gracenea M, Gomez MS, Torres J. 2009. Prevalence of Intestinal Parasites in Shelter Dogs and Cats in The Metropolitan Area of Barcelona (Spain). Acta Parasitol 54: 73-77.

Glickman L, Schantz P. 1981. Epidemiology and Pathogenesis of Zoonotic Toxocariasis. Epidemiologic Reviews 3: 230-250.

Hilderth A, Vantassel S, Hygnstrom S. 2010. Feral Cats and Threir Management. Lincoln. University of Nebraska.

Holland CV, Smith HV. 2006. Toxocara The Enigmatic Parasite. Wallingford UK. CABI Publishing 301.
Jiang P, Zhang X, Liu RD, Wang ZQ, Cui J. 2017. A Human Case of Zoonotic Dog Tapeworm, Dipylidium caninum (Eucestoda: Dilepidiidae), in China. Korean Journal of Parasitology 55(1): 6164.

Lin RQ, T JD, Zhou DH, Song HQ, Huang SH, C JX, Chen MX, Zhang H, Zhung XQ, Zhou XN. 2011. Prevalence of Clonorchis sinensis Infection in Dogs and Cats in Subtropical Southern China. Parasites and Vectors 4: 180.

Loliwu YA, Thalib I. 2012. Prevalensi Penyakit Cacing pada Ayam Buras di Desa Taende Dan Tomata Kecamatan Mori Atas Kabupaten Morowali. Jurnal Agropet 9(1): 69-83.

Mircean V, Titilincu A, Vasile, C. 2010. Prevalence of Endoparasites in Household Cat (Felis catus) Populations From Transylvania (Romania) and Association with Risk Factors. Vet Parasitol 171(12): 163-166.

My AHJ, Ridwan Y, Cahyaningsih U. 2013. Parasit Saluran Pencernaan pada Kucing Liar di Lingkungan Kampus Institut Pertanian Bogor. Bogor. Fakultas Kedokteran Hewan, Institut Pertanian Bogor. https://repository.ipb.ac.id/jspui/ bitstream/123456789/67311/1/ B13ahj_IPH.pdf

Nealma S, Dwinata IM, Oka IBM. 2013. The Prevalence of Toxocara cati in local cat in Denpasar. Indonesia Medicus Veterinus 2(4): 428-436.

Nicoulaud J, Yéra H, Dupouy-Camet J. 2005. Prevalence of Diphyllobothrium latum, L., 1758 Infestation in Perca fluviatilis from Lake Leman. Parasite 12(4): 362-364.

Oktaviana PA, Dwinata M, Oka IBM. 2014. The Prevalence of Ancylostoma spp. Infection in Local Cat (Felis catus) at Denpasar. Buletin Veteriner Udayana 6(2): 161-167.

Petney TN, Andrews RH, Saijuntha W, WenzMücke A, Sithithaworn P. 2013. The Zoonotic, Fish-Borne Liver Flukes Clonorchis sinensis, Opisthorchis felineus and Opisthorchis viverrini. International Journal for Parasitology 43(12-13): 10131046.

Prianto JLA, PU, Darwanto. 2001. Atlas Parasitologi Kedokteran. Jakarta. PT Gramedia Pustaka Utama. Pp. 8-117. 
Pujiastuti N. 2015. Identifikasi dan Prevalensi Ektoparasit pada Ikan Konsumsi di Balai Benih Ikan Siwarak. Unnes Journal of Life Science. 4(1): 9-15.

Purnomo, Gunawan JW, Magdalena LJ. 2009. Atlas Helmintologi Kedokteran. Jakarta. PT Gramedia Pustaka Utama. Hlm. 783.

Raji AA, Magaji AA, Bello MB, Lawal MD, Mamuda A, Yahaya MS. 2013. Prevalence of Gastrointestinal Parasites of Stray Cats: A Case Study of Two Hospitals in Sokoto Metropolis, Sokoto, Nigeria. $J$ Bacteriol Parasitol 4(4): 1-3.

Revenga JE. 1993. Diphyllobothrium dendriticum and Diphyllobothrium latum in Fishes From Southern Argentina: Association, Abundance, Distribution, Pathological Effects, and Risk Of Human Infection. J Parasitol 79(3): 379-383.

Riggio FR,Mannella, G. Ariti, S. Perrucci. 2013. Intestinal and Lung Parasites in Owned Dogs and Cats From Central Italy. Vet Parasitol 193(1-3): 78-84.

Sohn WM, Chai JY. 2005. Infection Status with Helminthes in Feral Cats Purchased From a Mmarket in Busan, Republic of Korea. Korean J Parasitol 43(3): 93-100.

Sucitrayani PTE, Oka IBM, Dwinata M. 2014. The Prevalence of Protozoa Intestinal Infection in Local Cat (Felis catus) at Denpasar. Buletin Veteriner Udayana 6(2): 153-159.
Sures B, Nachev M, Selbach C, Marcogliese DJ. 2017. Parasite Responses to Pollution: What We Know and Where We Go in 'Environmental Parasitology'. Parasites and Vectiors 10(65): 1-19.

Tang ZL, Huang Y, Yu XB. 2016. Current Status and Perspectives of Clonorchis sinensis and Clonorchiasis: Epidemiology, Pathogenesis, Omics, Prevention and Control. Infectious Diseases of Poverty 5(1): 1-12.

Ward E. 2009. Roundworm Infection in Cats. Kingsbrook Animal Hospital. Pp. 1-3.

WSPA (World Society for the Protection of Animals). 2008. Global Companion Animal Ownership and Trade: Project Summary, June 2008. http://www.wspainternational.org. [15 April 2019].

Yamamoto N, Kon M, Saito T, Maeno N, Koyama M, Sunaoshi K, Yamaguchi M, Morishima Y, Kawanaka M. 2009. Prevalence of Intestinal Canine and Feline Parasites in Saitama Prefecture, Japan. Kansenshogaku Zasshi 83(3): 223-228.

Yuniarti WM, Lukiswanto BS. 2013. Infeksi Dipylidium cacinum pada Kucing. Vetmedika Jurnal Klinik Veteriner 1(2): 52-55.

Zibaei M, Sadjjadi SM, Sarkari B. 2007. Prevalence of Toxocara cati and Other Intestinal Helminths in Stray Cats in Shiraz, Iran. J. Trop Biomed 24(2): 3943. 